\title{
Interdyscyplinarne perspektywy rozwoju, integracji i zastosowań ontologii poznawczych $^{26}$
}

\author{
Joanna Hastings I,IIIIII, ${ }^{*}$, Gwen A. Frishkoff ${ }^{\mathrm{IV}}$, Barry Smith ${ }^{\mathrm{V}}$, Mark Jensen ${ }^{\mathrm{V}}$, Russell \\ A. Poldrack ${ }^{\mathrm{VI}, \mathrm{VII}, \mathrm{VII}}$, Jane Lomax ${ }^{\mathrm{I}}$, Anita Bandrowski ${ }^{\mathrm{IX}}$, Fahim Imam ${ }^{\mathrm{IX}}$, Jessica A. \\ Turner $^{\mathrm{IV}, \mathrm{X}}$ i Maryann E. Martone ${ }^{\mathrm{IX}}$
}

Przełożył Przemysław Nowakowski

\begin{abstract}
Abstrakt
Przedstawiamy ostatnie postępy w rozwoju ontologii poznawczych i omawiamy trzy wyzwania dla skoordynowanego rozwoju i zastosowań tych zasobów. Wyzwaniem_1 jest przyjęcie zestandaryzowanej definicji procesów poznawczych. Opisujemy trzy możliwości i rekomendujemy jedną, spójną z tradycyjnym ujęciem w naukach poznawczych i biomedycznych. Wyzwaniem_2 jest harmonizacja [harmonization]. Luki i niezgodności w reprezentacjach muszą być usunięte, tak żeby zasoby
\end{abstract}

\footnotetext{
${ }^{26}$ Przekład artykułu pt. „Interdisciplinary perspectives on the development, integration, and application of cognitive ontologies" opublikowanego w Frontiers in Neuroinformatics, June 2014, Volume 8, Article 62, source:

https://www.frontiersin.org/articles/10.3389/fninf.2014.00062/full

DOI: 10.3389/fninf.2014.00062 Przekład opublikowano na mocy licencji Creative Commons Attribution License (CC BY).

* Korespondencja: Janna Hastings, European Molecular Biology Laboratory - European Bioinformatics Institute,Wellcome Trust Genome Campus, Hinxton, Cambridge, CB10 1SD, UK email: hastings@ebi.ac.uk

I European Molecular Biology Laboratory - European Bioinformatics Institute,Wellcome Trust Genome Campus, Hinxton, UK

II Department of Philosophy and Swiss Center for Affective Sciences, University of Geneva, Switzerland

III Evolutionary Bioinformatics, Swiss Institute for Bioinformatics, Lausanne, Switzerland IV Department of Psychology/Neuroscience Institute, Georgia State University, GA, USA

V Department of Philosophy and National Center for Ontological Research, University at Buffalo, NY, USA

VI Imaging Research Center, University of Texas at Austin, TX, USA

VII Department of Psychology, University of Texas at Austin, TX, USA

VIII Department of Neuroscience, University of Texas at Austin, TX, USA

IX Neuroinformatics Framework Project, University of California, San Diego, CA, USA

$\mathrm{X}$ Mind Research Network, Albuquerque, NM, USA
} 
mogły być połączone w celu oznaczania i interpretacji danych multimodalnych. Na koniec, wyzwaniem_3 jest przetestowanie użyteczności tych zasobów dla szeroko zakrojonej anotacji danych, zapytań i przeszukiwania oraz integracji i odkrywania wiedzy. Podczas gdy definicje terminów są testowane i poprawiane, harmonizacja powinna umożliwiać skoordynowane aktualizacje pomiędzy ontologiami. Jednak prawdziwym testem dla tych definicji będzie przyjęcie ich przez całą wspólnotę, która sprawdzi, czy wspierają one poprawne wnioskowania o danych psychologicznych i neuronaukowych.

Słowa kluczowe: ontologia, poznanie, funkcje umysłowe, neuronauka, anotacja, integracja, big data, nauki o mózgu

\section{Wprowadzenie}

Procesy umysłowe ujawniają się na wielorakich poziomach, od komórkowej dynamiki konsolidacji pamięci do sensorycznych i ruchowych zachowań, które angażują cały mózg i ciało. Stąd wyczerpujące rozumienie zjawisk połączonych z poznaniem wymaga przynajmniej skoordynowanej współpracy psychologii, biologii i neuronauk (Albus i in., 2007). W ciągu dwóch ostatnich dekad widzieliśmy bezprecedensowe kroki w tym kierunku, ze wzmożonym wykorzystaniem neuroobrazowania (PET i fMRI), neurofizjologii (EEG) i neurogenetyki, a także paradygmatów eksperymentalnych, pochodzących z psychologii poznawczej, klinicznej i neuropsychologii (Jones i Mendell, 1999).

Chociaż stosowanie tych metod pozwoliło na uzyskanie bogactwa wysokiej jakości danych o funkcjonowaniu umysłu ${ }^{27}$, większy postęp będzie wymagał nie tylko większej ilości danych, ale również nowych sposobów integrowania, przetwarzania i rozumienia danych (Decety i Cacioppo, 2010; Akil i in., 2011). Ontologia wyłoniła się ostatnio jako kluczowe narzędzie wspierające te wysiłki. Ontologia to formalna reprezentacja rodzajów bytów w danej dziedzinie wraz z ich własnościami i wzajemnymi relacjami. Ostatnie projekty, takie jak Cognitive Paradigm Ontology (CogPO; Turner i Laird, 2012), Neural Electromagnetic Ontologies (NEMO; Frishkoff i in., 2009, 2011a, 2011b) Neuroscience Information Framework (NIF; Gardner i in., 2008; Imam i in., 2012) i Cognitive Atlas (Poldrack i in., 2011), pokazują, że ontologie mogą być wykorzystywane do łączenia danych między neuronaukowymi bazami danych i innymi zasobami (np. Imam i in., 2012), a także do

\footnotetext{
${ }^{27}$ Ze względu na cele tego artykułu autorzy zgodzili się traktować „procesy umysłowe”, „funkcjonowanie umysłu” i „poznanie” jako synonimy. Zazwyczaj dokonuje się podziału pomiędzy nimi i choć w niektórych przypadkach występują dobre powody, by ich dokonać, to objaśnienia te wykraczają poza zakres naszej pracy.
} 
ułatwienia metaanaliz danych z neuroobrazowania (np. Laird i in., 2009; Frishkoff i in., 2011a; Fox i Friston, 2012; Turner i Laird, 2012).

Ten artykuł podsumowuje ostatnie wysiłki i opisuje trzy wyzwania stojące przed rozwojem i integracją ontologii poznawczych. Wyzwaniem_1 jest przyjęcie zestandaryzowanych definicji procesów poznawczych i integracja tych procesów w ramie dostarczanej przez ontologię podstawową (ogólną), współdzieloną $\mathrm{z}$ innymi ontologiami biomedycznymi. Opisujemy trzy możliwości i rekomendujemy jedną, spójną ze standardowym ujęciem w naukach poznawczych i biomedycznych.

Wyzwaniem_2 jest harmonizacja terminów w ontologiach. Przeszukanie dla „pamięci” w BioPortalu (Noy i in., 2009) przywołuje ponad 150 haseł z 30 ontologii ${ }^{28}$. Ten i inne terminy podstawowe, takie jak „percepcja”, „planowanie” i „emocje”, mają w ontologiach różnorodne, a czasami sprzeczne definicje. Te niezgodności muszą zostać pogodzone w celu połączenia różnorodnych ontologii, by oznaczać i interpretować dane multimodalne. W tym artykule opisujemy zakres kilku ontologii poznawczych i biomedycznych oraz sugerujemy, jakie obszary wymagają koordynacji dla ulepszenia ich rozwoju i zastosowań.

Wyzwaniem_3 jest testowanie użyteczności ontologii poznawczych do anotacji danych na szeroką skalę, zapytań i przeszukiwań oraz analiz opartych na ontologii. Podczas gdy wyzwanie_1 koncentruje się na rozwoju ontologii, wyzwanie_2 i wyzwanie_3 odzwierciedlają zainteresowanie ich harmonizacją i zastosowaniem. Podczas testowania i poprawiania definicji terminów, harmonizacja powinna umożliwiać skoordynowane aktualizacje pomiędzy ontologiami. Jednak prawdziwym testem dla tych definicji będzie to, czy będą wspierały poprawne wnioskowania na temat danych psychologicznych i neuronaukowych. Razem z konkluzjami przedstawimy nasze spojrzenie na przyszły rozwój i zastosowanie ontologii poznawczych.

\section{Wyzwanie \#1: definiowanie i klasyfikowanie procesów umysłowych}

Celem dla unifikacji biologii, neuronauk, psychologii i dziedzin pokrewnych jest zrozumienie relacji pomiędzy funkcjonowaniem umysłu a aktywnością mózgu. Ontologia ogólna, taka jak Basic Formal Ontology (BFO; Smith i Grenon, 2004), może dostarczyć klas integracji niezależnych od dziedziny oraz relacje łączące dziedziny, mogące służyć za punkt wyjścia dla anotacji danych wyłaniających się z tego skomplikowanego poszukiwania zrozu-

\footnotetext{
${ }^{28} \mathrm{http}$ :/bioportal.bioontology.org/search?query=memory\&commit=Search
} 
mienia. Byty anatomiczne takie jak centralny system nerwowy klasyfikowane są jako obiekty $\mathrm{w}$ ramach BFO. BFO pozwala również na „wytwarzanie” części danych obiektów w celu ich klasyfikacji, arbitralnego (ale przydatnego) dzielenia na sekcje, np. system nerwowy podzielny jest na system centralny i obwodowy, chociaż są one ciągłe fizycznie dzięki połączeniom nerwów znajdujących się w każdej z części. Aktywność mózgu w BFO jest sklasyfikowana jako proces, a byty anatomiczne są powiązane ze sobą dzięki relacji uczestniczenia w tych procesach.

W BFO istnieją trzy sposoby możliwego reprezentowania relacji pomiędzy procesami umysłowymi i mózgowymi (Frishkoff, 2012). Zgodnie z pierwszym ujęciem procesy umysłowe są odrębne od procesów fizycznych (np. mózgowych). Jest to ujęcie psychologii potocznej i reprezentuje rodzaj dualizmu: istnieją byty fizyczne i byty niefizyczne (umysłowe). Drugie i trzecie ujęcie, $w$ przeciwieństwie do pierwszego, reprezentuje procesy umysłowe jako podklasę procesów fizjologicznych (cielesnych). Drugie ujęcie charakteryzuje procesy umysłowe jako rodzaj procesów cielesnych, odrębny od procesów mózgowych, natomiast trzecie ujęcie utrzymuje, że procesy umysłowe są podtypem procesów mózgowych.

Pierwsze ujęcie, dualizm, może generować hipotezy, które są trudne lub niemożliwe do testowania w ramach nauki, a jego naukowa niepopularność jest uzasadniona. Ujęcie drugie i trzecie, przeciwnie, są spójne z tym, co wiemy o fizjologicznych podstawach poznania. Obydwa przyjmują, że procesy umysłowe to procesy fizyczne, chociaż trzecie ujęcie idzie o jeden krok dalej, przyjmując, że procesy umysłowe ujawniają się wyłącznie w mózgu, a nie $\mathrm{w}$ systemie autonomicznym (reprodukcyjnym, trawiennym) czy zmysłowych i ruchowych obszarach obwodowych (np. rękach, stopach). Ujęcia te są spójne $\mathrm{z}$ większością tego, co wiemy o funkcjach sensomotorycznych, motywacji, emocjach oraz bardziej złożonych procesach poznawczych. Z drugiej strony, jeśli pragniemy uchwycić także bardziej ucieleśnione ujęcie poznania, możemy dowodzić, że interakcje pomiędzy mózgiem a ciałem (procesami trzewnymi i somatycznymi) są nieodłączne od poznania, dlatego nie chcielibyśmy wykluczać procesów fizjologicznych poza mózgiem z reprezentowania zjawisk umysłowych. Z tego powodu rekomendujemy zarówno podejście drugie, jak i trzecie jako rozsądny punkt początkowy ontologii poznawczych.

Jak każdy system złożony poznanie zawiera rozmaite podsystemy. Większość badaczy zgodziłoby się, że podsystemy poznawcze zawierają co najmniej percepcję, uwagę, pamięć krótko- i długotrwałą, podejmowanie decyzji, język i emocje (James, 1890; Poldrack i in., 2011). Wszelka ontologia funkcjonowania umysłu prawdopodobnie będzie więc zawierać terminy właśnie dla tego rodzaju zjawisk. Jednak można dokonać dokładniejszych 
rozróżnień. Teorie poznania różnią się tym, czy i jak dokonują tych rozróżnień oraz jak podsystemy zakładane przez teorię zdają się wchodzić w interakcje i prowadzą do wzorców zachowań.

Zjawiska umysłowe nie mogą być obserwowane w ten sam sposób co zachowanie czy aktywność mózgu. Badanie naukowe musi więc „operacjonalizować” lub określać procesy poznawcze w odniesieniu do poszczególnych podejść eksperymentalnych. W tym celu badacze opracowali różnorodne paradygmaty eksperymentalne (Turner i Laird, 2012). Każdy paradygmat zawiera zbiór jawnych instrukcji dla badanych, by zachowywali się w określony sposób (np. uważali, wciskali przycisk) w odpowiedzi na różne bodźce (np. słowa czy twarze). Miary wyników zawierają zarówno czas i dokładność reakcji, jak i wzorce aktywności fizjologicznej (cielesnej czy mózgu). Przykładowo Fliessbach ze współpracownikami (2010) testował, jak siła pamięci (zoperacjonalizowana w kategoriach dokładności odpowiedzi ) zależy od sposobu, w jaki ludzie uczą się albo kodują nowe informacje. Niektórzy uczestnicy byli proszeni o dokonanie sądów ortograficznych (litery), podczas gdy inni o dokonanie sądów semantycznych (znaczenia). Wyniki pokazały, że przywoływanie z pamięci jest lepsze dla zadań semantycznych, dostarczając tym wsparcia dla rozpoznawanego w psychologii pamięci konstruktu, znanego jako „głębia przetwarzania”. To badanie obrazuje, jak zmienne eksperymentalne są wykorzystywane do operacyjnego definiowania zjawisk umysłowych. Jednocześnie zauważamy, że definicje operacyjne opierają się na konkretnych metodach pomiaru, które mogą być niewrażliwe na wszystkie aspekty interesujących nas zjawisk lub mogą odzwierciedlać procesy dodatkowe, np. tak zwane wymagania zadania. Dlatego zbieżność świadectw z testowania wielorakich metod jest istotna dla badań nad poznaniem.

W tym kontekście baza danych BrainMap (Laird i in., 2005) i Cognitive Paradigm ontology (Rysunek 1; Turner i Laird, 2012) były wykorzystywane do anotacji danych o mózgu i zachowaniu, by testować hipotezy na temat relacji między zachowaniem i mózgiem. BrainMap jest dużym kontrolowanym repozytorium badań nad poznaniem, przeprowadzonych przy pomocy neuroobrazowania, które mogą zostać wykorzystane do zbadania związków pomiędzy zachowaniem i wzorcami aktywności mózgowej (głównie z PET i fMRI). Koduje ono główne metadane eksperymentu, wliczając $w$ to warunki, zadania, odpowiedzi oraz metody pomiaru. Używając tej struktury, wyniki eksperymentalne mogą zostać zgrupowane na podstawie obiektywnych podobieństw pomiędzy bodźcami, instrukcjami zadań i pomiarami niezależnie od tego, czy eksperyment był zaprojektowany do badania poszczególnego podsystemu, takiego jak pamięć, funkcje wykonawcze czy uwaga (Burns i Turner, 2013). 


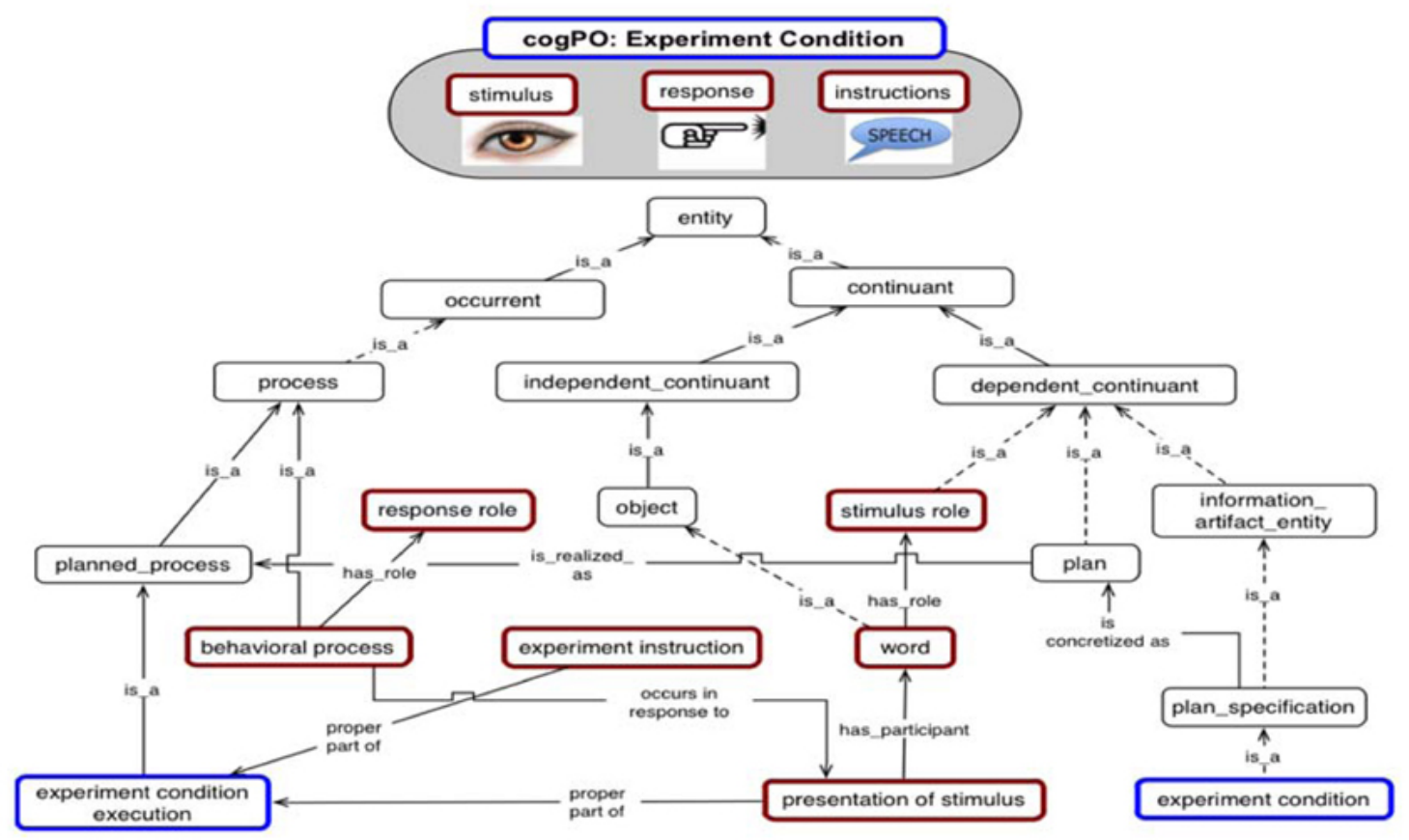

Ilustracja 1. Reprezentacja części Cognitive Paradigm Ontology (CogPO)

\section{Wyjaśnienie ilustracji 1}

\begin{tabular}{|l|l|}
\hline Nad drzewem & $\begin{array}{l}\text { Niebieski: CogPO: Warunki doświadczalne; Czerwone: } \\
\text { bodziec/reakcja/instrukcja }\end{array}$ \\
\hline Drzewo_Rząd1 & Byt \\
\hline Drzewo_Rząd2 & Okurent/kontynuant \\
\hline Drzewo_Rząd3 & Proces/kontynuant_niezależny/kontynuant_zależny \\
\hline Drzewo_Rząd4 & $\begin{array}{l}\text { planowany_proces; Czerwony: rola reakcji; przedmiot; Czerwony: rola bodźca; } \\
\text { plan; informacja_artefakt_byt }\end{array}$ \\
\hline Drzewo_Rząd5 & $\begin{array}{l}\text { Czerwony: proces behawioralny/Instrukcja eksperymentalna/świat; } \\
\text { plan_specyfikacja }\end{array}$ \\
\hline Drzewo_Rząd6 & $\begin{array}{l}\text { Niebieski: warunki doświadczalne/wykonanie; Czerwony: prezentacja bodźca; } \\
\text { Niebieski:warunki doświadczalne }\end{array}$ \\
\hline $\begin{array}{l}\text { Operatory } \\
\text { (znajdujące się } \\
\text { wewnątrz linii) }\end{array}$ & $\begin{array}{l}\text { is_a - jest; has_role - gra rolę; is_realized_as - jest realizowany jako; } \\
\text { is_concetrized_as - jest; konkretyzowany jako; proper part of - właściwa część; } \\
\text { occurs in response to - pojawia się w; odpowiedzi na; has_participant - ma } \\
\text { uczestnika }\end{array}$ \\
\hline
\end{tabular}


Cognitive Atlas (Poldrack i in., 2011) reprezentuje komplementarne starania. Wykorzystując styl Wikipedii (lub podejście „bazar”; Raymond, 1999), Cognitive Atlas wychwytuje szeroki zakres terminologii używanej w naukach poznawczych, odnosząc miary operacyjne do rodzajów funkcji umysłowych, do mierzenia których zostały zaprojektowane. Przykładowo Cognitive Atlas zawiera stwierdzenia takie jak " «zadanie porównywania wzorców» ${ }^{29}$ mierzące "zdolność przetwarzania»"30.

W neuropsychologii klinicznej miary behawioralne i samoopisu (nazywane „testami neuropsychologicznymi”) są powszechnie wykorzystywane w diagnozie i leczeniu pacjentów z zaburzeniami psychologicznymi i rozwojowymi. Oceny neurologiczne opierają się na teorii, zgodnie z którą natura i lokalizacja uszkodzenia mózgu, zarówno w wyniku choroby, jak i urazu, mogą być odkryte przez testowanie funkcji poznawczych pacjenta. NeuroPsychological Testing Ontology (NPT ${ }^{31}$ ) była używana do charakteryzowania tych testów, które zawierają miary zdolności poznawczych, takich jak przywoływanie $\mathrm{z}$ pamięci krótko- kontra długotrwałej lub funkcje wykonawcze. Neurological Disease Ontology $\left(\mathrm{ND}^{32}\right)$ klasyfikuje byty ważne dla chorób neurologicznych, takich jak Alzheimer i stwardnienie rozsiane. Choroby są klasyfikowane oraz powiązane z kryteriami diagnostycznymi i neuropatologią. Kluczowym wyzwaniem neuronauki klinicznej i poznawczej jest rozumienie jak zaburzenia fizjologiczne spowodowane przez urazy lub choroby są powiązane z deficytami poznawczymi, takimi jak utrata pamięci czy afazja. Spodziewamy się, że harmonizacja NPT, ND i podobnych zasobów będzie wspierała ten cel.

\section{Wyzwanie \#2: interoperacyjność ontologii poznawczych}

Dotychczas wspomnieliśmy o kilku ontologiach poznawczych. W ostatnich latach psychologia przyjęła metody i spostrzeżenia nauk biologicznych, włączając genetykę molekularną, biologię ewolucyjną i fizjologię (Kandel, 2008). Metody te ukazują mózg w rozmaitych rozdzielczościach przestrzennych od genów po mapy neuronalne oraz systemy w interakcji. Badania medyczne również coraz częściej zwracają się ku biologicznym świadectwom przy wyjaśnianiu zaburzeń umysłowych takich jak depresja i schizofrenia (Weyandt, 2006), w wyniku czego aktualnie wiele bio-ontologii zawiera również terminologię dotyczącą procesów umysłowych.

\footnotetext{
${ }^{29} \mathrm{http}: / /$ www.cognitiveatlas.org/task/id/trm_4da86cb034ff6

${ }^{30} \mathrm{http} / / /$ www.cognitiveatlas.org/concept/id/trm_4a3fd79d0adf4

${ }^{31} \mathrm{http}: / /$ code.google.com/p/neuropsychological-testing-ontology/

${ }^{32} \mathrm{http} / / /$ code.google.com/p/neurological-disease-ontology/
} 
Przykładowo Gene Ontology (GO), powszechnie używana do międzygatunkowych anotacji funkcji wytworów genów (Ashburner i in., 2000), zawiera między innymi terminy dla „poznania”, „uczenia” i „pamięci”. Tej międzydziedzinowej różnorodności ontologii, które zawierają terminologię dla bytów poznawczych, towarzyszy różnorodność definicji i klasyfikacji.

By koordynować prace pomiędzy dziedzinami i promować konwergencję Open Biomedical Ontologies OBO Foundry (Smith i in., 2007) rekomenduje najlepsze praktyki w rozwijaniu ontologii, takie jak ponowne wykorzystywanie istniejących terminów, zaangażowanie wspólnoty (tzn. bycie „otwartym”) oraz standaryzację praktyk dotyczących metadanych. Zgodnie z naszą wiedzą standardy te przyczyniają się do jakości i interoperacyjności ontologii neuronaukowych i poznawczych. Przykładowo ontologie te w większości przyjęły BFO jako wspólną ontologię ogólną, powszechne jest też wykorzystywanie ontologii dziedzinowych [mid-level ontologies], takich jak OBI, IAO, OGMS i UBERON, co pokazuje Tabela 1. To ponowne wykorzystywanie gwarantuje, że odpowiadające sobie terminy z ontologii współdzielą dokładnie ten sam identyfikator i definicję, a przez to bezproblemowo harmonizują wynikające anotacje danych.

Tabela 1. Przegląd prac nad ontologiami poznania i dziedzin pokrewnych

\begin{tabular}{|l|l|l|l|l|l|l|}
\hline Nazwa/RRID & Lokalizacja & Status & Źródło & Zakres & $\begin{array}{l}\text { Ontologia } \\
\text { Ogólna }\end{array}$ & $\begin{array}{l}\text { Ontologia } \\
\text { Powiązane }\end{array}$ \\
\hline $\begin{array}{l}\text { MentalFunction- } \\
\text { ing Ontology } \\
\text { (MF)/ } \\
\text { RRID:nlx_157305 }\end{array}$ & $\begin{array}{l}\text { http://purl.bioon } \\
\text { tology. org/on- } \\
\text { tology/MF }\end{array}$ & Alfa & $\begin{array}{l}\text { Hastings et } \\
\text { al. (2012) }\end{array}$ & $\begin{array}{l}\text { Procesy } \\
\text { poznawcze i } \\
\text { dyspozycje }\end{array}$ & BFO 2.0 & $\begin{array}{l}\text { OBI/IAO, } \\
\text { OGMS }\end{array}$ \\
\hline $\begin{array}{l}\text { CognitivePara- } \\
\text { digm Ontology } \\
\text { (CogPO)/ } \\
\text { RRID:nlx_155537 }\end{array}$ & $\begin{array}{l}\text { http://purl.bioon } \\
\text { tology. org/on- } \\
\text { tology/COGPO }\end{array}$ & $\begin{array}{l}\text { Wersja } \\
\text { (v1.0) }\end{array}$ & $\begin{array}{l}\text { Turner and } \\
\text { Laird (2012) }\end{array}$ & $\begin{array}{l}\text { Poznawcze } \\
\text { paradygmaty } \\
\text { eksperyment } \\
\text { alne }\end{array}$ & BFO 1.0 & $\begin{array}{l}\text { OBI/IAO, } \\
\text { BrainMap }\end{array}$ \\
\hline $\begin{array}{l}\text { Neural Electro- } \\
\text { magnetic Ontol- } \\
\text { ogies (NEMO)/ } \\
\text { RRID:nif-0000- } \\
\text { 10899 }\end{array}$ & $\begin{array}{l}\text { http://purl.bioon } \\
\text { tology. org/on- } \\
\text { tology/NEMO }\end{array}$ & $\begin{array}{l}\text { Wersja } \\
\text { (v3.2) }\end{array}$ & $\begin{array}{l}\text { Frishkoff et } \\
\text { al. (2009) }\end{array}$ & $\begin{array}{l}\text { Poznanie i } \\
\text { procesy } \\
\text { mózgowe } \\
\text { (pomiary } \\
\text { EEG i ERP) }\end{array}$ & BFO 1.0 & $\begin{array}{l}\text { OBI/IAO, } \\
\text { NIFSTD, } \\
\text { CogPO, UO }\end{array}$ \\
\hline $\begin{array}{l}\text { Neuroscience In- } \\
\text { formation }\end{array}$ & $\begin{array}{l}\text { http://purl.bioon } \\
\text { tology. org/on- } \\
\text { tology/NIFSTD }\end{array}$ & $\begin{array}{l}\text { Wersja } \\
\text { (v2.9) }\end{array}$ & $\begin{array}{l}\text { Imam et al. } \\
(2012)\end{array}$ & $\begin{array}{l}\text { Anatomia } \\
\text { mózgu } \\
\text { (międzygatu } \\
\text { nkowa) }\end{array}$ & BFO 1.0 & $\begin{array}{l}\text { OBI/IAO, } \\
\text { UBERON, } \\
\text { CogPO }\end{array}$ \\
\hline
\end{tabular}




\begin{tabular}{|c|c|c|c|c|c|c|}
\hline $\begin{array}{l}\text { Frame- } \\
\text { work(NIFSTD)/ } \\
\text { RRID:nlx_144512 }\end{array}$ & & & & & & \\
\hline $\begin{array}{l}\text { CognitiveAt- } \\
\text { las(COGAT)/ } \\
\text { RRID:nif-0000- } \\
24591\end{array}$ & $\begin{array}{l}\text { http://purl.bioon } \\
\text { tology.org/ on- } \\
\text { tology/COGAT }\end{array}$ & $\begin{array}{l}\text { Wersja } \\
\text { (v1.0) }\end{array}$ & $\begin{array}{l}\text { Poldrack et } \\
\text { al. (2011) }\end{array}$ & $\begin{array}{l}\text { Procesy } \\
\text { poznawcze, } \\
\text { poznawcze } \\
\text { paradygmaty } \\
\text { eksperyment } \\
\text { alne }\end{array}$ & - & CogPO \\
\hline $\begin{array}{l}\text { Neurological } \\
\text { Disease Ontol- } \\
\text { ogy (ND)/ } \\
\text { RRID:nlx_157304 }\end{array}$ & $\begin{array}{l}\text { http://code.googl } \\
\text { e.com/p/ neuro- } \\
\text { logical-disease- } \\
\text { ontology/ }\end{array}$ & Alfa & $\begin{array}{l}\text { Jensen et al. } \\
(2013)\end{array}$ & \begin{tabular}{|l|} 
Zaburzenia \\
neurologiczn \\
e, \\
neuropatolog \\
ie
\end{tabular} & BFO 2.) & $\begin{array}{l}\text { OBI, GO, } \\
\text { OGMS, CL, } \\
\text { ChEBI, PR }\end{array}$ \\
\hline $\begin{array}{l}\text { Neuro Behav- } \\
\text { ioral Ontology } \\
\text { (NBO)/ } \\
\text { RRID:nlx_151745 }\end{array}$ & $\begin{array}{l}\text { http://purl.bioon } \\
\text { tology.org/ on- } \\
\text { tology/NBO }\end{array}$ & Beta & $\begin{array}{l}\text { Gkoutos et al. } \\
(2012)\end{array}$ & $\begin{array}{l}\text { Procesy } \\
\text { behawioraln } \\
\text { e, fenotypy }\end{array}$ & - & $\begin{array}{l}\text { GO, ChEBI, } \\
\text { UBERON }\end{array}$ \\
\hline $\begin{array}{l}\text { NeuroPsycholog- } \\
\text { ical Test- } \\
\text { ingOntology(NP } \\
\text { T)/ } \\
\text { RRID:nlx_157303 }\end{array}$ & $\begin{array}{l}\text { https://code.goog } \\
\text { le.com/p/ neuro- } \\
\text { psychological- } \\
\text { testing- ontol- } \\
\text { ogy/ }\end{array}$ & Alfa & $\begin{array}{l}\text { Cox et al. } \\
(2013)\end{array}$ & $\begin{array}{l}\text { Oceny } \\
\text { poznawcze, } \\
\text { miary } \\
\text { behawioraln } \\
\text { e }\end{array}$ & BFO 2.0 & OBI/IAO \\
\hline \multicolumn{7}{|c|}{$\begin{array}{l}\text { OBI, Ontology of Biological Investigations; IAO, Information Artifact Ontology; OGMS, Ontology for } \\
\text { General Medical Science; UO, Units Ontology; UBERON, Uber Anatomy Ontology; CL, Cell Ontology; } \\
\text { ChEBI, Chemical Entities of Biological Interest Ontology; PR, Protein Ontology. Wszystkie ontologie } \\
\text { dostępne pod adresem http://www.obofoundry.org/ }\end{array}$} \\
\hline
\end{tabular}

Przewodnią zasadą OBO Foundry jest realizm ontologiczny, który zakłada, że ontologie winny mieć za swój cel „identyfikację rodzajów bytów, które istnieją... W zgodzie $\mathrm{z}$ najlepszym, aktualnym rozumieniem naukowym” (Smith i Ceusters, 2010). Realizm ontologiczny jest podstawą BFO i, w naszym ujęciu, efektywnie wspiera skoncentrowanie całej wspólnoty na reprezentowaniu wiedzy naukowej. Co interesujące, ontologiczny realizm, jak się wydaje, może być kwestionowany z powodu konieczności reprezentowania pewnych zjawisk umysłowych, takich jak halucynacje, które odnoszą się do nieistniejących bytów. Jednym z rozwiązań jest odróżnienie tych procesów, które mogą być ujmowane jako niekanoniczne, od kanonicznej percepcji, w której reprezentacje percepcyjne wyzwalane są przez bodźce zmysłowe. Percepcja jest relacyjna, w tym sensie, że ukazuje podmiot w świecie w kontakcie z zewnętrznym przedmiotem (Mulligan i Smith, 1986). Tak jak Foundational Model of Anatomy (FMA; Rosse 
i Mejino, 2003) zawiera terminy dla ramienia i nogi, ale nie dla poamputacyjnego kikuta czy uschłego ramienia. Ontologie, które reprezentują kanoniczne procesy umysłowe, zawierają terminy na percepcję wzrokową czy słuchową, lecz nie na synestezję czy szumy uszne. W konsekwencji terminy takie należałyby do ontologii powiązanych ze szczególnymi rodzajami chorób umysłowych i neurologicznych (Ceusters i Smith, 2010). Koncentrując się na przypadku kanonicznym, (przykładowo) procesy percepcyjne mogą spokojnie być zdefiniowane jako reprezentujące przedmioty i angażujące przekonania na temat tych przedmiotów. Następnym wyzwaniem jest więc uchwycenie relacji pomiędzy procesami kanonicznymi i niekanonicznymi, uznając, że niektóre centralne podprocesy w normalnej percepcji są podobne lub nawet identyczne z tymi (np.) przy doświadczaniu halucynacji.

\section{Wyzwanie \#3: zastosowania ontologii poznawczych}

Poza anotacją i integracją danych ontologie mogą być wykorzystane do udoskonalenia przeszukiwania i odkrywania innych zasobów, a także do wnioskowań opartych na danych zarówno w obrębie eksperymentów, jak i między nimi.

\section{Odkrywanie informacji}

Neuroscience Information Framework ${ }^{33}$ (NIF) pozwala na przeszukiwanie i odkrywanie w szerokiej gamie zasobów, wliczając w to publikacje, bazy danych oraz inne źródła informacji. Wyszukiwarka opiera się na ontologii NIF (NIFSTD), co zapewnia lepszą formalizację i integrację istniejących zasobów. Przykładowo ontologie zawierają oparte na semantyce odwzorowania pomiędzy powiązanymi terminami, takimi jak „poznanie” i „procesy umysłowe”, dlatego przeszukanie oparte na ontologii zawierającej tylko jeden $\mathrm{z}$ tych terminów nadal ma doskonały zasięg.

\section{Anotacja danych}

W coraz większym stopniu ontologie wykorzystywane są do anotacji danych. Przykładowo zachowania organizmów modelowych są powszechnie używane jako pośrednik w badaniach procesów i zaburzeń umysłowych u ludzi (np. Cryan i Holmes, 2005; Wu i Luo, 2005; Mathur i Guo, 2010). Neu-

\footnotetext{
${ }^{33}$ http://www.neuinfo.org/
} 
roBehavioral Ontology (NBO; Gkoutos i in., 2012), oparta na GO, reprezentuje zachowanie i służy do anotacji danych o organizmie modelowym. Formalizacja relacji pomiędzy zachowaniem a przypuszczalnymi homologiami $\mathrm{w}$ funkcjach umysłowych reprezentowanymi w ontologiach będzie wspierać lepszą integrację i translację danych w tej dziedzinie.

\section{Analizy oparte na ontologii}

Wreszcie ontologie mogą zostać wykorzystane do wnioskowania między danymi, np. do klasyfikacji złożonych wzorców (jako wspierane przez NEMO; Bilder i in., 2009; Frishkoff i in., 2009, 2011a, 2011b; Poldrack $\mathrm{i}$ in., 2012).

By umożliwić zastosowania międzydziedzinowe, Hastings ze współpracownikami (2012) zaproponował Mental Functioning Ontology (MF), zawierającą pośredniczące między ontologiami m oduły p o m os tow e. Moduły pomostowe przypisują związki semantyczne, takie jak tożsamość, bycie częścią czy realizacja, terminom z różnych ontologii. Moduły te istnieją niezależnie od wszelkich ontologii źródłowych, ale mogą być zastosowane do bezpiecznego nawiązywania do obu ontologii, wykorzystując bazujące na wiedzy relacyjne powiązania między nimi. Nasza wizja jest taka, że MF będzie wspierać harmonizację narzędzi do przeszukiwania i analiz między danymi biochemicznymi, biologicznymi i medycznymi. W ten sposób pragniemy osiągnąc silniejsze powiązanie między badaniami biologicznymi („naukami podstawowymi”), translacyjnymi i dokumentacją medyczną. Ze względu na jawne związki pomiędzy kategoriami zaburzeń i niskopoziomowymi procesami umysłowymi przewidujemy, że MF może pomóc w dalszym ujednoznacznianiu danych $\mathrm{w}$ kategoriach diagnostycznych $\mathrm{w}$ przypadku zaburzeń umysłowych, które cechują się wysokim poziomem współwystępowania (Hastings i Schulz, 2012).

\section{Perspektywy: czego potrzebujemy w przyszłości?}

W kilku ostatnich latach stworzono wiele ontologii do reprezentowania, anotacji i wnioskowań na temat funkcji umysłowych oraz reprezentowania powiązanych danych dotyczących mózgu i zachowania w różnych kontekstach eksperymentalnych. Tabela 1 przedstawia przegląd tych starań. Obecnie nie istnieje jeden projekt łączący te wysiłki, chociaż występuje znaczące „zapylanie krzyżowe”, przedstawiane przez kolumnę „Powiązane”, zawierającą ontologie dziedzinowe, które są podzielane przez projekty. 
Dla badaczy odwzorowywanie pomiędzy ontologiami może stanowić wyzwanie - niezależne ontologie mogą odzwierciedlać różne założenia, praktyki metodologiczne, naukowe punkty widzenia (co znajduje odzwierciedlenie, przykładowo, w niezgodnych definicjach). Ponowne i samodzielne wykonywanie odwzorowań przez każdego użytkownika połączonych danych badawczych jest nieefektywne i podatne na błąd, a problemy w hamonizowaniu utrudniają integrację wiedzy zawartej w odpowiednich anotacjach w szersze rozumienie obejmujące genetyczne, molekularne, komórkowe i psychologiczne poziomy opisu. W miarę postępu nauki każda $\mathrm{z}$ tych ontologii rozwinie się $\mathrm{w}$ nieznacznie odmienny sposób, czyniąc w przyszłości wszelkie odwzorowania potencjalnie nieaktualnymi.

Bardziej niż odwzorowań post hoc, opartych na wysiłkach podejmowanych z projektu na projekt, potrzebujemy skoordynowanych międzynarodowych działań dążących do integracji ontologii. Integracja ta wymaga tworzenia modułów pomostowych pomiędzy ontologiami, które dokładnie odzwierciedlają podzielane rozumienie związków semantycznych pomiędzy bytami z różnych ontologii. Jest to konieczne, by umożliwić porównanie i dopasowanie (a dzięki temu maksymalnie efektywnie wykorzystanie) empirycznych danych badawczych, pochodzących z różnych źródeł i metodologii. Dopóki ontologie i anotacje (dane) są rozdzielne, integracja oparta na ontologii nie zmieni sposobu, w jaki pracują badacze z różnych obszarów i w żaden sposób nie narzuci im niechcianych ram teoretycznych lub metodologicznych. Integracja oparta na ontologii wypływa raczej z wykorzystywania zbioru wspólnych i zintegrowanych ontologii do anotacji danych. Wierzymy, że dzięki pewnym skoordynowanym staraniom możliwe będzie stworzenie takich powszechnych ontologii (poczyniliśmy już pewne kroki w tym kierunku, jak wcześniej pisaliśmy) w sposób, który pozostanie neutralny względem różnych podejść metodologicznych i założeń podstawowych.

Wierzymy, że postęp wymaga (a) ciągłego wykorzystywania przez badaczy, tworzących dane pierwotne istniejących ontologii do anotacji oraz deponowania tych anotowanych danych we wspólnych repozytoriach wraz z (b) opartą na ontologii integracją przez wytwarzanie podzielanych semantycznych modułów pomostowych między ontologiami oraz zwiększanie konwergencji (rekomendowane przez OBO Foundry) w ponownym używaniu podzielanych komponentów pomiędzy różnymi ontologiami, podzielanymi ontologiami ogólnymi i dziedzinowymi oraz podzielanymi standardami dotyczącymi metadanych.

Obecnie opieramy się na istniejącej, aktywnej współpracy pomiędzy twórcami ontologii i pracujemy nad tym, by stworzyć zbiór zasobów, za czym będzie mogła stanąć różnorodna, interdyscyplinarna wspólnota badaczy. 
Będzie to wymagało skoordynowanych działań na szeroką skalę. Jednak w czasach nauki coraz bardziej opierającej się na danych, skoncentrowanej na ich starannym przechowywaniu i udostępnianiu, co prowadzi do powtarzalności wyników, wierzymy, że nigdy nie było to bardziej potrzebne ani nie było ku temu lepszej okazji.

\section{Wnioski}

Opisaliśmy ostatnie prace nad rozwojem ontologii poznawczych i ich wykorzystaniem przy anotacji, integracji oraz analizie klinicznych i poznawczych danych neuronaukowych. Wspólnym celem jest zidentyfikowanie klas zachowań i aktywności mózgu powiązanych z różnymi typami procesów umysłowych. Ten ambitny zamiar jest spójny z niedawnymi apelami o szeroko zakrojone mapowanie mózgu i wsparcie dla neuronauki translacyjnej (np. Neuroimaging Informatics Tools and Resources Clearinghouse; Human Brain Project; the Brain Initiative - Devor i in., 2013), projekty te $z$ pewnością zyskają na rozwoju i harmonizacji ontologii poznawczych. Istnieje paląca potrzeba, by skoordynować starania między powiązanymi dziedzinami. NIF odgrywa tu kluczową rolę jako łączący „hub” i główny „konsument” wielu wyników działań, powiązanych z opisanymi tu ontologiami. Istnieje realna potrzeba, by dostarczyć jasnych i wypracowanych przez wspólnotę definicji centralnych, ogólnych bytów w ramach tej dziedziny, aby jednak ten wysiłek się powiódł, niezbędna jest szeroko zakrojona współpraca całej wspólnoty.

\section{Deklaracja dotycząca konfliktu interesów}

Autorzy deklarują, że badania były prowadzone bez żadnego komercyjnego i finansowego wsparcia, które mogłoby być uznane za konflikt interesów.

\section{Podziękowania}

W lipcu 2012 roku w Graz w Austrii międzynarodowa, interdyscyplinarna grupa badaczy spotkała się, by przedyskutować aktualny stan ontologii poznawczych w różnych dyscyplinach (kr-med.org/icbofois2012/mfo/). Bezpośrednie spotkanie było poprzedzone serią wirtualnych seminariów organizowanych przez NIF. Autorzy dziękują profesorowi Stefanowi Schulzowi za wsparcie w przebiegu warsztatu w Graz. Dziękują również wszystkim uczestnikom warsztatu i serii seminariów, które go poprzedzały, za udział w dyskusji. Praca ta była częściowo wspierana przez Swiss Centre for 
Affective Sciences. Wsparcie finansowe, które umożliwiło otwarty dostęp do tej publikacji, zostało zapewnione przez EMBL.

\section{Literatura}

Akil, H., Martone, M. E., Van Essen, D. C. (2011). Challenges and opportunities in mining neuroscience data. Science, 331, 708-712. doi: 10.1126/science.1199305.

Albus, J. S., Bekey, G. A., Holland, J. H., Kanwisher, N. G., Krichmar, J. L., Mishkin, M, \& in. (2007). A proposal for a decade of the mind initiative. Science, 317, 1321. doi: 10.1126/science.317.5843.1321b.

Ashburner, M., Ball, C. A., Blake, J. A., Botstein, D., Butler, H., Cherry, J. M., \& in. (2000). Gene ontology: tool for the unification of biology. Nature Genetics, 25, 2529. oi: $10.1038 / 75556$.

Bilder, R. M., Sabb, F. W., Parker, D. S., Kalar, D., Chu, W. W., Fox, J., \& in. (2009). Cognitive ontologies for neuropsychiatric phenomics research. Cognitive Neuropsychiatry, 14, 419-450. doi: 10.1080/13546800902787180.

Burns, G. A. P. C. \& Turner, J. A. (2013). Modeling functional magnetic resonance imaging (fMRI) experimental variables in the ontology of experimental variables and values (OoEVV). Neuroimage 15, 662-670. doi: 10.1016/j.neuroimage.2013.05.024.

Ceusters, W., \& Smith, B. (2010). Foundations for a realist ontology of mental disease. Journal of Biomedical Semantics 1, 10, 1-23. doi: 10.1186/2041-1480-1-10.

Cox, A. P., Jensen, M., Ruttenberg, A., Szigeti, K. \& Diehl, A. D. (2013). Measuring cognitive functions: hurdles in the development of the neuropsychological testing ontology, w Proceedings of the 4th International Conference on Biomedical Ontology 2013, Montreal, QC.

Cryan, J. F. \& Holmes, A. (2005). Model organisms: the ascent of mouse: advances in modelling human depression and anxiety.Nature Review Drug Discovery, 4, 775790. doi: $10.1038 / \mathrm{nrd} 1825$.

Decety, J. \& Cacioppo, J. (2010). Frontiers in human neuroscience: the golden triangle, and beyond. Perspectives of Psychological Science, 5, 767-771. doi: 10.1177/1745691610388780.

Devor, A., Bandettini, P. A., Boas, D. A., Bower, J. M., Buxton, R. B., Cohen, L. B., \& in. (2013). The challenge of connecting the dots in the B.R.A.I.N, Neuron, 80, 270-274. doi: 10.1016/j.neuron.2013.09.008.

Fliessbach, K., Buerger, C., Trautner, P. \& Elger, C. E., Weber, B. (2010). Differential effects of semantic processing on memory encoding. Human Brain Mapping, 31, 1653-1664. doi: 10.1002/hbm.20969.

Fox, P. T. \& Friston, K. J. (2012). Distributed processing; distributed functions? Neuroimage, 61, 407-426. doi: 10.1016/j.neuroimage.2011.12.051. 
Frishkoff, G. (2012). Mental functioning is neural functioning: towards a unified ontology of mind, brain, and behavior, w Proceedings of the Workshop on Mental Functioning Ontologies at the International Conference on Biomedical Ontology (ICBO'12)> Graz.

Frishkoff, G., Frank, R.\& LePendu, P. (2011a). Ontology-based analysis of event-related potentials, w Proceedings of the International Conference on Biomedical Ontology 2011> Buffalo, NY.

Frishkoff, G., Sydes, J., Mueller, K., Frank, R., Curran, T., Connolly, J., \& in. (2011b). Minimal Information for Neural Electromagnetic Ontologies (MINEMO): a standards-compliant method for analysis and integration of event-related potentials (ERP) data. Standard Genomic Sciences, 5, 211-223. doi: 10.4056/sigs.2025347.

Frishkoff, G., LePendu, P., Frank, R., Liu, H. \& Dou, D. (2009) Development of Neural Electromagnetic Ontologies (NEMO): Ontology-based tools for representation and integration of event-related brain potentials. w Proceedings of the International Conference on Biomedical Ontology 2009. Buffalo, NY.

Gardner, D., Akil, H., Ascoli, G. A., Bowden, D. M., Bug, W., Donohue, D. E., \& in. (2008). The Neuroscience Information Framework: a data and knowledge environment for neuroscience. Neuroinformatics, 6, 149-160. doi: 10.1007/s12021008-9024-z.

Gkoutos, G. V., Schofield, P. N., Hoehndorf, R. (2012). The Neurobehavior Ontology: an ontology for annotation and integration of behavior and behavioral phenotypes.bIntenationalReview Neurobiology, 103, 69-87. doi: 10.1016/B978-0-12388408-4.00004-6.

Hastings, J., le Novère, N., Ceusters, W., Mulligan, K., Smith, B. (2012). Wanting what we don't want to want: representing addiction in interoperable bio-ontologies, w Proceedings of the 3rd International Conference on Biomedical Ontology 2012, Graz, 897.

Hastings, J., Schulz, S. (2012). Ontologies for human behavior analysis and their application to clinical data. Internationa Review Neurobiology, 103, 89-107. doi: 10.1016/B978-0-12-388408-4.00005-8.

Imam, F. T., Larson, S. D., Bandrowski, A., Grethe, J. S., Gupta, A., and Martone, M. E. (2012). Development and use of ontologies inside the neuroscience information framework: a practical approach. Frontiers in Genetics, 3(111). doi: 10.3389/fgene.2012.00111.

James, W. (1890). The Principles of Psychology, Vol. 2. Dover Publications: New York, NY. Doi: 10.1037/10538-000.

Jensen, M., Cox, A. P., Chaudhry, N., Ng, M., Sule, D., Duncan, W., \& in. (2013). The neurological disease ontology. Journal of Biomedical Semantics, 4(42). doi: $10.1186 / 2041-1480-4-42$

Jones, E. \& Mendell, L. M. (1999). Assessing the decade of the brain. Science, 284, 739. doi: 10.1126/science.284.5415.739. 
Kandel, E. R. (2008). Psychiatry, Psychoanalysis, and the New Biology of Mind. American Psychiatric Publishing: Arlington, VA.

Laird, A. R., Lancaster, J. L. \& Fox, P. T. (2005). BrainMap: the social evolution of a functional neuroimaging database. Neuroinformatics, 3, 65-78. doi: 10.1385/NI:3:1:065

Laird, A. R., Lancaster, J. L. \& Fox, P. T. (2009). Lost in localization? The focus is metaanalysis. Neuroimage , 48, 18-20. doi: 10.1016/j.neuroimage.2009.06.047.

Mathur, P. \& Guo, S. (2010). Use of zebrafish as a model to understand mechanisms of addiction and complex neurobehavioral phenotypes. Neurobiology of Disease, 40, 66-72. doi: 10.1016/j.nbd.2010.05.016.

Mulligan, K. \& Smith, B. (1986). A Relational Theory of the Act. Topoi, 5, 115-130. doi: 10.1007/BF00139225.

Noy, N. F., Shah, N. H., Whetzel, P. L., Dai, B., Dorf, M., Griffith, N., \& in. (2009). BioPortal: ontologies and integrated data resources at the click of a mouse. Nucleic Acids Research, 37(Suppl. 2), W170-W173. doi: 10.1093/nar/gkp440.

Poldrack, R. A., Kittur, A., Kalar, D., Miller, E., Seppa, C., Gil, Y. \& in. (2011). The Cognitive Atlas: towards a knowledge foundation for cognitive neuroscience. Frontiers in Neuroinformatics, 5(17). doi: 10.3389/fninf.2011.00017.

Poldrack, R. A., Mumford, J. A., Schonberg, T., Kalar, D., Barman, B. \& Yarkoni, T. (2012). Discovering relations between mind, brain, and mental disorders using topic mapping. PLoS Computational Biology , 8:e1002707. doi: 10.1371/journal.pcbi.1002707

Raymond, E. S. (1999).The Cathedral and the Bazaar. O'Reilly \& Associates, Inc: Sebastopol, CA.

Rosse, C.\& Mejino, J. L. (2003). A reference ontology for biomedical informatics: the foundational model of anatomy. Journal of Biomedical Informatics, 36, 478-500. doi: 10.1016/j.jbi.2003.11.007.

Smith, B., Ashburner, M., Rosse, C., Bard, C., Bug, W., Ceusters, W. \& in. (2007). The OBO Foundry: coordinated evolution of ontologies to support biomedical data integration. Natature Biotechnology, 25, 1251-1255. doi: 10.1038/nbt1346.

Smith, B. \& Ceusters, W. (2010). Ontological realism: a methodology for coordinated evolution of scientific ontologies. Applied Ontology, .5, 139-188.

Smith, B. \& Grenon, P. (2004). The cornucopia of formal-ontological relations. Dialectica, 58, 279-296. doi: 10.1111/j.1746-8361.2004.tb00305.x

Turner, J. A.\& Laird, A. R. (2012). The cognitive paradigm ontology: design and application. Neuroinformatics, 10, 57-66. doi: 10.1007/s12021-011-9126-x

Weyandt, L. L. (2006). The Physiological Bases of Cognitive and Behavioral Disorders. RoTaylor and Francis: Routledge. 
Wu, Y. \& Luo, Y. (2005). Transgenic C. elegans as a model in Alzheimer's research. Current Alzheimer Research, 2, 37-45. doi: 10.2174/1567205052772768

\begin{abstract}
We discuss recent progress in the development of cognitive ontologies and summarize three challenges in the coordinated development and application of these resources. Challenge 1 is to adopt a standardized definition for cognitive processes. We describe three possibilities and recommend one that is consistent with the standard view in cognitive and biomedical sciences. Challenge 2 is harmonization. Gaps and conflicts in representation must be resolved so that these resources can be combined for mark-up and interpretation of multi-modal data. Finally, Challenge 3 is to test the utility of these resources for large-scale annotation of data, search and query, and knowledge discovery and integration. As term definitions are tested and revised, harmonization should enable coordinated updates across ontologies. However, the true test of these definitions will be in their community-wide adoption which will test whether they support valid inferences about psychological and neuroscientific data.
\end{abstract}

Keywords: ontology; cognition; mental functioning; neuroscience; annotation; integration; big data; brain science 